\title{
Las causas de la caída del Imperio Inca Bajo la perspectiva del Inca Garcilaso de la Vega: una visión teológica del confronto entre el Conquistador Español y el Inca Atahualpa
}

\author{
Elton Emanuel Brito Cavalcante - UNIR
}

\section{Resumen}

Este trabajo tiene como objeto Los Comentarios Reales del Inca Garcilaso de la Vega. Aquí el objetivo es contestar a la pregunta: ¿Por qué se cayó el Imperio Inca a manos de un grupo diminuto de soldados españoles, hambrientos y cansados? De entre las varias respuestas posibles, se acatará la que pone la caída como un proceso aún en marcha de cumplimiento de la profecía dada por Dios a Abrahán, de que este sería el padre de una infinidad de naciones. Para justificar ese punto de vista, se tendrá por base la tesis de Garcilaso de que en el Imperio Inca mucho había de común con la tradición y costumbres abrahámicas, sobre todo en tratándose del mito de la creación del Cusco, puesto que el mito describe de forma similar el periplo del patriarca bíblico y su esposa hasta Canaán. Adviértase que el parangón que aquí se hace no tiene nada que ver con la cuestión del catolicismo haberse sobrepuesto o no a las religiones indígenas, puesto que Abrahán es patriarca de judíos, cristianos y musulmanes, incluso llegando a India, China y Japón. Así, el profeta no pertenecía a ninguna de estas religiones, pues su misión era la de encaminar el hombre hacia la noción de Dios, el creador, el que saca el hombre de la salvajería y le enseña a huir del mal. Por lo tanto, entre los mismísimos incas, algo de la idea abrahámica ya existía, aunque aplastada por el culto al dios incaico central, el sol. Por lo tanto, el intento aquí no es el de decir que una religión es mejor que la otra, sino el de demostrar que en la de los incas ya había, como lo dijo Garcilaso, el germen de la fe abrahámica.

Palabras clave: Imperio Inca; Conquista; Garcilaso de la Vega; religión; Atahualpa; Huáscar. 


\title{
The causes of the fall of the inca empire: a theological vision of the confrontation between Francisco Pizarro and the Inca Atahualpa
}

\begin{abstract}
This work is a reinterpretation of the book The Real Commentaries of the Inca Garcilaso de la Vega. Here the objective is to answer the question: Why did the Inca Empire fall into the hands of a tiny group of Spanish soldiers, hungry and tired? Among the various possible answers, the one that puts the fall as an ongoing process of fulfillment of the prophecy given by God to Abraham, that he would be the father of an infinity of nations. The Garcilaso's thesis is that in the Inca Empire there was much in common with the tradition and Abrahamic customs, especially in the case of the myth of the creation of Cusco, because it describes similar the journey of the biblical patriarch and his wife to Canaan. Note that the comparison made here has nothing to do with the issue of Catholicism overcoming or not indigenous religions: Abraham is patriarch of Jews, Christians and Muslims, even reaching India, China and Japan. Thus, the prophet did not belong to any of these religions, because his mission was to direct man towards the notion of God, the creator, the one who brings man out of savagery and teaches him to flee from evil. Therefore, among the very Incas, something of the Abrahamic idea already existed, although crushed by the worship of the central Inca god, the sun. Therefore, the intent here is not to say that one religion is better than the other, but to demonstrate that in the Incas there was already, as Garcilaso said, the germ of the Abrahamic faith.
\end{abstract}

Keywords: Inca Empire; Conquest; El Inca Garcilaso de la Vega; religion; Atahualpa; Huáscar.

\section{Introducción}

En visita al Cusco, me encontré con las grandes construcciones del Imperio Inca. Interesado por historia, resolví leer algún literato peruano que abordase la cultura incaica. ¿Y por quién empezar? Por el Inca Garcilaso de la Vega, por supuesto. Así, pronto me compré la obra Los Comentarios Reales y, mientras la leía, me surgió una duda: ¿Por qué los incas cayeron ante un grupo reducido de soldados españoles, hambrientos y haraposos?

Supe que para contestarla debía conocer los motivos que llevaron a los conquistadores españoles a arriesgar sus vidas en tierras tan hostiles; asimismo analizar el mundo inca, su historia, sus logros; y, por fin, la vida e intereses del propio Inca Garcilaso, quien tuvo una existencia agitada justamente por ser fruto de la mezcla de dos grandes imperios, pertenecía a la vez a la nobleza inca y a la española, siendo hijo de una princesa aborigen con un capitán español. 
Las causas de la caida del Imperio Inca Bajo la perspectiva del Inca Garcilaso de la Vega: 287 una visión teológica del confronto entre el Conquistador Español y el Inca Atabualpa

Asimismo, hablé con las personas de la calle, guías turísticos, mercaderes, mendigos, ambulantes, etc., muchos de los cuales apenas tenían idea del Imperio inca, puesto que la mayoría de sus conocimientos inherentes al asunto venía de la necesidad de tratar con los turistas, por lo mismo debían estar al tanto de algo para transmitírselo a los viajeros ávidos de curiosidades. Aunque no tenían datos científicos, sus puntos de vista servían para fomentarme el interés sobre el asunto.

Pronto me percaté de una cosa: el confronto entre el inca y el español es tratado de forma apasionada e ideológica entre los intelectuales. Hay los que defienden el Imperio Inca con uñas y dientes; otros que lo tachan de malo. Algunos analizan el encuentro de las dos culturas, la amerindia y la europea, a través de la perspectiva anticapitalista y antieuropea y, por consiguiente, inculpan a los conquistadores de entremeterse en tierras y asuntos ajenos; otros, empero, aseveran haber sido inevitable la caída del Imperio, casi un castigo por los rituales sangrientos, idolatrías y violencia con que Atahualpa, el imperador inca, trató a su hermano tras vencerlo en la guerra civil.

Yo adopté algunos rasgos de la última hipótesis, por lo que buscaré demostrar que los imperios en su esencia son malos y que la caída del mundo inca no se dio solamente por cuestiones económicas, políticas y materiales, sino también por el cumplimiento de la profecía bíblica en la que Dios le dijo a Abrahán que la descendencia espiritual de este sería tan numerosa como las estrellas del cielo. Tal profecía no ha sido dada a un pueblo, sino a un hombre, que vivió y murió por la fe. El judaísmo, cristianismo e islam no pasan de partes del cumplimiento de la promesa irrevocable de Dios.

Los Cometarios Reales difunden esta noción, es decir, la venida del cristianismo a América es un plan divino que está por encima de las meras causas político-económicas. Eso no conlleva decir que yo esté de acuerdo con la forma con la que la Iglesia romana o la Corona española realizaron el cumplimiento de la profecía, ni tampoco con la manera que los remanentes del Imperio inca continúan siendo tratados por las repúblicas y democracias cristianas.

Lo que sí afirmo es que, pese a los abusos del poder y lo malo del expansionismo territorial por medio de la fuerza, el cristianismo se esparció por el continente, tornándose el sostén de pueblos ante la desesperación y la muerte e infundiendo el monoteísmo abrahámico. Lo mismo se puede decir del islam en el Oriente Medio, o sea, a su tiempo esta religión fue la 
conquistadora y colonizadora de la región, imponiéndose sobre las diversas formas de expresiones religiosas que allí existían.

\section{Lo Malo de los Imperios}

\subsection{El primer conquistador}

En el libro de Génesis, Dios dijo que el hombre debería multiplicarse, pero no expandirse en detrimento de los demás. Se puede inferir que la vida ideal sería en pequeñas comunidades, típicamente rurales. En las grandes ciudades, el hombre comenzó a poner su fe más en sí mismo que en lo divino. En ellas, la codicia y el orgullo prevalecieron.

Nemrod, rey babilónico, quizá el idealizador de la Torre de Babel, fue el primero poderoso arquitecto y conquistador tras el Diluvio. Hizo grandes ciudades y las dominó con mano de hierro. Asimismo, se le considera el prototipo de los dictadores: se hizo un imperio, esclavizó a animales y hombres, todo en nombre de la riqueza. Fue considerado un dios, pues logró darles estabilidad económica a sus correligionarios.

Creó también la mezcla entre religión y Estado, y persiguió a los discrepaban de sus ideas. Es decir, el reino de la bestia busca la riqueza económica para pocos, el apego exagerado a los bienes terrenales y persigue a los inocentes.

La caída de la Torre es un mensaje atemporal a todos aquellos que confían en sí mismos en demasía. Ella se desplomó porque el hombre empezó a vivir sin medidas, cuestionó lo divinal y quiso cambiar las reglas de la naturaleza humana. Cuando eso ocurre, viene la bonanza material, que carga una onda de libertad, que, por su turno, genera críticas a la tradición y, por fin, desemboca en violencia, descaso, aborto, sexo desmedido, es decir, todo lo que la ciudad del hombre anhela.

\subsection{Colón: por las buenas o por las malas}

1492 fue el año del descubrimiento por los europeos de lo que vendría a ser el continente americano. Cristóbal Colón tras los primeros contactos con los aborígenes escribió a los Reyes Católicos sobre aquellos: "Luego todos se tornarían cristianos; y así espero en Nuestro Señor que Vuestras Altezas se determinarán a ello. Con mucha diligencia para tornar la Iglesia tan grandes pueblos, y los convertirán, así como han destruido aquellos que 
Las causas de la caida del Imperio Inca Bajo la perspectiva del Inca Garcilaso de la Vega: 289 una visión teológica del confronto entre el Conquistador Español y el Inca Atabualpa

no quisieron confesar el Padre, y el Hijo y el Espíritu Santo" (Colón, 2003, p. 20). Colón, hombre del Humanismo-Renacimiento, reflejaba bien el momento en que vivía el recién formado Imperio español, que, en verdad, no pasaba de un montón de reinos unidos, a veces por la fuerza, cuya corona buscaba enfrentarse a dos enemigos a la vez: el islam, al sur; y, al norte, el avance de los principios materialistas oriundos del antiguo mundo greco-romano.

En la cita, el navegador genovés habla de conversión religiosa por las buenas o las malas, lo que genera una duda: ¿Cómo explicar las violencias provocadas por el reino español hacia los pueblos originarios, en vista de que ello parece ser un contrasentido si se mira desde la perspectiva cristiana, que pregona la fraternidad entre los hombres? Una de las explicaciones es que el espíritu de Roma jamás se ha alejado de Europa, por esta razón los primeros patriarcas de la Iglesia intentaron arduamente separar la cizaña del trigo, es decir, combatieron duramente dos rasgos de dicha nación: la depravación moral, que en ciertas épocas prevaleció demasiadamente allí, y la impronta bélico-expansionista tan común al ADN romano.

\subsection{Pablo, Agustín y Platón: entre fe y razón}

El rechazo al paganismo era una de las metas de San Agustín (1981), quien señalaba haber dos ciudades, la de Dios y la del hombre. La primera es espiritual; la segunda, material y tendenciosa al pecado. Roma, con su codicia, pertenecería a la segunda. El filósofo dijo que los dioses romanos eran ángeles rebeldes transformados en demonios a raíz del pecado, y por lo mismo incentivadores de todos los males por los cuales el país vivió. Según él, si el Imperio se derrumbó no fue a causa del avance del cristianismo, sino de la propia anarquía espiritual y materialista en que se mantuvo por siglos.

San Agustín, empero, no pregonaba contra el pueblo en sí, tampoco menoscababa a todos los pensadores paganos oriundos de la cultura grecoromana, sino al hecho de las elites económicas, políticas e intelectuales del imperio haberse encaminado hacía actitudes consideradas innaturales, lo que generó malos ejemplos, luego esparcidos a las demás naciones. Por más que se intente mermar lo malo en Calígula y Nerón, por ejemplo, los hechos de estos son demasiadamente escalofriantes, incluso para la época.

Roma, por lo tanto, sería para el obispo de Hipona el gran ejemplo de descalabro social, puesto que sus dioses, paradojamente, conducirían el pueblo a la impiedad. Describe el filósofo ritos practicados en aquella ciudad, en los cuales la perversión sexual tocaría a la inmundicia, algunos financiados 
o permitidos por el Estado. El materialismo estaba en lo sumo a punto de que, en muchas ocasiones, los que participaban de dichos cultos ni siquiera creían en las deidades, y si los frecuentaban sería más por honor a la tradición que por confianza en fuerzas inmateriales.

Agustín pidió a sus contrincantes que le apuntasen ejemplos de enseñanza sana para el alma y cuerpo revelados por los dioses del panteón romano. Criticó incluso el mito de origen de la ciudad, erigida bajo el fratricidio: Rómulo habría asesinado a su hermano por tierras, comparándolo así al Caín bíblico. El pensador cristiano apuntaba que, inclusive en los momentos áureos de la monarquía, república e imperio, lo que había siempre regido los rumbos de la ciudad había sido el afán material, el deseo de poses, la codicia, la expansión territorial, el robo, la mentira, el genocidio. En consecuencia, ilustra, bastaría con ver el amor a los juegos de sangre en el Coliseo para advertirse de que el romano promedio se entretenía con la violencia, y todo eso en honor a sus dioses.

Sin embargo, demostró asimismo haber habido romanos piadosos que intentaron rescatar el bien vivir al encaminar el hombre hacia la ciudad de Dios, especies de profetas que, por intuición de lo divino, vivan de forma similar a los profetas del verdadero cristianismo, aunque sin conocerlo. Hombres como Cicerón, Séneca o Marco Aurelio pretendieron frenar el instinto salvaje de los humanos, mostrándoles como quebrantar la carne para elevar el espíritu. Pero incluso tales pensadores aún vivirían bajo el signo de la ciudad del hombre, en vista de que la expansión imperialista no había sido por ellos combatida. En algunos casos, recrudeció, como es el de Marco Aurelio, gran filósofo, íntegro en el actuar, no obstante haber en su cuenta miles de hombres y mujeres esclavizados debido a la codicia del pueblo romano. El imperador filósofo, creyendo ser Roma la luz civilizadora que alumbraría la barbarie de los pueblos salvajes, les impuso por paga la dureza de la espada.

Por ello, de entre los filósofos del mundo greco-romano, fue Platón el maestro principal de San Agustín, para quien el pensamiento del griego podría ser compatible con el del apóstol Pablo. En efecto, Platón rechazaba los excesos de las pasiones y ponía en un mundo metafísico la verdadera existencia, pero no lo hizo como en el budismo, el cual pregona la aniquilación total de la voluntad humana. Para él escopo no sería la aniquilación de la voluntad, sino su control. Combatió el teatro, sobre todo 
Las causas de la caída del Imperio Inca Bajo la perspectiva del Inca Garcilaso de la Vega: 291 una visión teológica del confronto entre el Conquistador Español y el Inca Atabualpa

la comedia, puesto que esta se reía de todo, incluso de lo que convendría ser tratado con seriedad. Una sociedad en la que prevaleciera la voluntad por encima de la razón, conduciría gradualmente el hombre a la salvajería. Para el pensador ateniense, la sociedad libertina arrastraría al irrespeto generalizado, que desembocaría en la anarquía. La única forma, por lo tanto, de evitar eso sería que la nación estuviese bajo los auspicios de los filósofos.

Aquí comienzan las discrepancias entre Platón y Pablo, puesto que el primero creía que el mundo divinal se podría alcanzar por medio de la razón, mientras que él apóstol, aunque una mente brillante, puso la fe por encima de la razón. Quizá por eso los intentos del filósofo ateniense han quedado vanos, pues quiso cambiar el mundo utilizándose del pragmatismo racionalista, mientras Pablo demostraba ante todo el control de sí mismo y la fe suprema en el Altísimo, insistiendo en la fuga de los deseos imperialistas, carnales y materiales.

Pese a esa fundamental diferencia, el neoplatonismo de San Agustín fue el faro del catolicismo medieval, que buscó implantar la anhelada ciudad de Dios en la Tierra. Sin embargo, esta buena intención ha sido corrompida siglos después, pues, en nombre de la vida eterna, se persiguió y mató a personas que poseían credos religiosos distintos. Nada más lejos de las enseñanzas de Jesús, quien dijo a sus discípulos que llevasen el evangelio a todos los rincones, pero dejó claro que muchos no aceptarían la verdad, y que el castigo de ellos ya estaba dado, puesto que serían apartados cuando viniera el Juicio Divinal. Jesucristo no les mandó a matar o herir a nadie. En verdad, había derogado cuantiosas normas habidas por buenas por los fariseos, y una de ellas era justo la de utilizarse de la violencia para combatir a los enemigos, reforzando así la eterna ley: "No matarás."

El Nuevo Testamento pregona el amor fraternal no sólo entre judíos, sino a todos los humanos, independiente de su nación, edad, color, etc. Jesús vino a libertar al hombre de la cárcel material: su mensaje es de autocontrol, de arrepentimiento de los errores y de la fe absoluta en el Creador. Jesús podría simplemente eliminar a los hipócritas, pero si así hubiese actuado negaría la voluntad del Padre, que le dio al hombre el libre albedrio. Por lo mismo, el humano tiene el derecho divino de elegir entre el bien y el mal. Así, la única arma verdadera contra el enemigo es, según el Maestro, creer que la voluntad divina prevalecerá sobre los impíos, no por la mano del hombre, como muchos lo desean, sino por amor de Dios a la humanidad. 


\subsection{Medievo, Reforma e islam}

El expansionismo cristiano medieval mezcló el reino de Dios, pregonado por Jesús, con el de los hombres. La expansión de las buenas nuevas de Jesús, basadas en la fe y amor al prójimo, se unieron a la expansión de la ciudad de los hombres, tan a gusto de Roma. Aunque Jesús haya prohibido el expansionismo bélico, este, desafortunadamente, había prevalecido. ¿Dónde está escrito que Jesús proclamó la guerra como forma de resolver los litigios?

Si el catolicismo tuvo sus momentos de exceso, la Reforma luterana tampoco mermó el instinto bélico humano, pues luego de ella surgieron conflictos armados, que fueron en contra de aquello que los Evangelios dictaminan.

Lo mismo se puede decir del islam, puesto que un sinnúmero de mahometanos, aunque hayan obtenido de Jesús los Evangelios, no dejaron que tales ideas calaran en lo más profundo de sus corazones.

Mahoma fue una especie de rey árabe, y nadie contesta su valor y coraje. Las tribus árabes vivían en pequeños grupos, casi siempre rivales entre sí. El profeta les impuso la unidad político-religiosa. Sus mensajes pueden ser grosso modo divididos en dos fases en relación a la tolerancia religiosa: la cristiana y la del jefe de Estado. En la primera, los escritos del Corán hablan de paz, hermandad, y Jesús Cristo surge en todo su esplendor.

Sin embargo, poco antes de tornarse jefe absoluto, Mahoma pasó a actuar de forma distinta: trataba a sus enemigos con poca tolerancia si no aceptaran la nueva fe, incluso a judíos y cristianos. Luego de la muerte del profeta, comenzaron las guerras de sucesión, las cuales provocaron profunda escisión en el islam. Es decir, todo lo contrario de lo que dijo Jesús, cuyo evangelio es siempre de convencimiento argumentativo, basado en la fe, jamás por medio del odio y la destrucción. En este punto, los líderes del islam parecen más a caudillos que a Jesús y son similares a los líderes del cristianismo medieval.

Como todo imperio, el islam no se mantuvo en el camino de la paz por amor a la Ciudad de los Hombres. Se expandió de manera análoga a la de Roma, buscando inclusive apropiarse del Mediterráneo. Llegó hasta la Península Ibérica, y los pueblos que allí vivían tuvieron que elegir entre aceptarlo o huir hacia las montañas del Norte. Los ibéricos se vieron invadidos por una fe que, aunque semejante a la suya, negaba lo esencial: la divinidad de Jesús.

Para Silio (1969), no obstante, la invasión árabe parece haber sido más perjudicial a las oligarquías dominantes que al restante de la población. 
Las causas de la caída del Imperio Inca Bajo la perspectiva del Inca Garcilaso de la Vega: 293 una visión teológica del confronto entre el Conquistador Español y el Inca Atabualpa

Él afirma que el islam se extendió sobre una región ya acostumbrada con invasiones imperialistas, puesto que los pueblos originarios de la Península estuvieron bajo el mando de fenicios, griegos, cartagineses, romanos y visigodos. Estos comandaban la Península cuando vinieron los moros. Por consiguiente, dice el autor, hubo apenas un cambio de señorío.

\subsection{La España imperialista}

El siglo XV se dio la unificación de los reinos de Castilla y Aragón. El nuevo reino, apoyado por una institución religiosa que decía amén al avance imperialista de Castilla y Aragón, tenía por meta dos cosas: por un lado, la expulsión total de todo no cristiano de la Península y la búsqueda de nuevas rutas hacia India. Es gracias a este contexto de políticas económicas expansionistas que los reyes católicos le permiten a Colón irse a su famoso viaje, llegando en 1492 a las islas caribeñas.

Según Prescott (1980), los colonizadores españoles no actuaron diferentemente de sus ancestros, que lucharon bajo la fe católica contra el yugo musulmán. De hecho, se creía que atosigar, en nombre de Jesús, un infiel o exilar judíos, quemar herejes era lo correcto. A pesar del cristiano verse obligado a expandir su fe, en ningún momento, como ya se dijo arriba, Jesús permitió la violencia. No obstante, la Iglesia participó indirectamente de atrocidades contra los amerindios. Las actitudes del colonizador en América, comparadas con las del período de dominio musulmán en la Península, fueron quizá más perniciosas.

El mandamiento no robarás también pregona contra el expansionismo imperialista, pues este se basa en la intimidación y expropiación. Los líderes políticos cristianismos a veces se olvidan de eso. Sin embargo, hay que aclararse un punto: algunas de las órdenes religiosas católicas no compartían la forma como el Estado español actuaba hacia el indígena, y trabaron lucha encarnizada contra las masacres. Muchísimos clérigos pusieron se arriesgaron para evitárselas.

Hoy día, sin embargo, incluso tales clérigos sufren críticas, pues es difícil para los agredidos aceptarlos como verdaderos defensores de la causa indígena, en vista de que al fin y al cabo terminaban por contribuir para la aculturación de los pueblos amerindios. Algunos académicos de rasgos indígenas ponen en duda la buena disposición de dichas órdenes religiosas y creen ser los hechos de sus sacerdotes tan solo la forma amena con que el imperio se utilizó para mejor conquistar. Quienes piensan así no se percatan 
de que, incluso hoy, hay misioneros que se embreñan en las selvas americanas o africanas con el sincero interés de ayudar a los indígenas, y obedeciendo a la orden de Jesús, que dijo que solo vendría de nuevo cuando el Evangelio fuese declarado a todos los humanos. ¿Cómo no llevarse en consideración eso, es decir, el hecho de que durante la conquista y colonización hubo hombres y mujeres con esta intención pura?

Pero ese deseo sencillo de los verdaderos cristianos, según los críticos, se casó perfectamente con los intereses expansionistas de los segmentos codiciosos de Castilla. Es obvio que la corona española deseaba convertir a los indígenas al catolicismo, a lo mejor menos por cuestiones espirituales que políticas. No se puede decir con certeza que Isabel de Castilla y Fernando I fuesen deshonestos en lo tocante a su fe, es decir, que todo lo que pregonaban del catolicismo y de Jesús fuese tan solo propaganda política. Hay documentos que atestan la disposición de la corona en proteger a los pueblos americanos. Si esta disposición era sincera, tampoco se puede decir con clareza.

Lo que sí se puede hablar es que Fernando I fue el modelo de príncipe ideal para Maquiavelo. ¿Y cuáles los atributos valorados por el escritor italiano? La astucia y la disposición de Fernando I en hacer prevalecer el imperio por medio de acciones no siempre éticas y permitidas por Dios, justificando los medios por los fines alcanzados. Por ello, tampoco se puede decir con seguridad que muchas de las actitudes de las cortes españolas estuviesen de hecho preocupadas con los no españoles. Si estuviesen de verdad, según los evangelios, habían de hacer lo que Cristo impuso: no robarás, no matarás, amarás a tu prójimo como a ti mismo. Pero la avaricia preponderó, y el discurso oficial afirmaba que, si miles hubiesen de morir a causa de trabajos forzados para garantizar la felicidad de la mayoría, todo estaría bien...

\subsection{La educación formal y el expansionismo}

En 1517 ocurrió la Reforma religiosa, lo que impondría un ritmo nuevo respecto a la educación formal en Europa. Aunque la Contrarreforma oficialmente solo empezaría a partir de 1545, eso no implica que la Iglesia romana en ese tramo se mantuviese inerte al avance protestante. En verdad, naciones como España, donde el catolicismo prevalecía, frenaron fuertemente el avance de los ideales humanistas-renacentistas que hasta entonces llenaban el espíritu de los peninsulares. Los conflictos religiosos, pese al cataclismo de las guerras fratricidas, tuvo consecuencias fundamentales, una de ellas fue la preocupación con la educación del pueblo. Católicos y protestantes 
Las causas de la caída del Imperio Inca Bajo la perspectiva del Inca Garcilaso de la Vega: 295 una visión teológica del confronto entre el Conquistador Español y el Inca Atabualpa

se empeñaron en educar a sus fieles, siempre con el intuito de sofocar las sectas opuestas. Así, escuelas y universidades nacieron intentando conciliar o evitar el avance científico.

Los protestantes se volverían más conservadores, y sus doctrinas buscaban volver al grado de moralización pregonados por los primeros cristianos. Esa aura de pureza encontrará guarida en los puritanos que vinieron a colonizar la parte norte del continente. Los católicos también pasaron a preocuparse más con las conductas morales de su grey. Los jesuitas, aunque se les critique, no hay como negar que, al menos desde una perspectiva europea, contribuyeron con la elevación intelectual de los americanos.

En efecto, la Iglesia romana en su afán de expansionismo religioso, y, por supuesto, en su combate al protestantismo, dejó un legado de importantes ciudades, universidades y grandes pensadores para la incipiente América. Durante la colonización, las ciudades más relucientes eran las de origen español y portugués, puesto que los ingleses y franceses, los dos otros pueblos colonizadores, no tuvieron ni el ánimo de expandir el cristianismo entre los aborígenes, ni tampoco el de crear ciudades que pudiesen hacer frente a las del Viejo Continente.

Es verdad que los indígenas sufrieron tanto allá en el Norte como acá en el Sur de América, pero, como se dijo, hay registros que atestiguan la lucha de algunos católicos en pro de la vida aborigen. Pero desgraciadamente eran ellos minoritarios, pues la mayoría sí estaba en concierto con los intereses de la corona. El propio Pizarro se utilizó del ideal católico para justificar sus atrocidades, y lo hizo de la forma más cruel y maquiavélica posible para apropiarse de tierras que no le pertenecían. En consecuencia, la manera como él y los suyos terminaron refleja bien el castigo por sus malos hechos.

De entre los pueblos precolombinos, dos se destacan por su poder y esplendor, los aztecas y los incas, estos últimos de gran ingenio y sagacidad. Pero el imperio inca no era hecho de ángeles, sino que tenían los mismos ideales de la Ciudad de los Hombres, en vista de que su núcleo estaba hecho de un grupo étnico que se consideraba superior a los demás pueblos conquistados. Tal grupo actuó con los pueblos dominados de forma dura, no tanto como hicieron los españoles con ellos, sino como lo hicieron los musulmanes con los ibéricos. Pero el deseo de expansión les estaba presente, y las atrocidades morales y sociales también les eran frecuentes, como se verá a continuación. 


\section{Orígenes del Imperio Incaico}

\subsection{Los antecesores}

El Imperio Inca no fue el único, a lo mejor ni siquiera el más complejo de la región de los Andes, pero incontestablemente es el más esplendido de los hallados allí. Antes que él, hubo varias ciudades-estado con rasgos imperialistas que, a medida del tiempo, se iban cayendo a manos de otras más pujantes. Ninguna, no obstante, fue tan extensa territorialmente y organizada como la nación inca, que, al igual que Roma, absorbió el conocimiento de los antiguos imperios que le precedieron. Eso demuestra su espíritu pragmático y emprendedor. Por ello, no es cierta la propaganda que se les imputa a los incas, es decir, que fueron un pueblo que se hizo de la nada al construirse obras monumentales de ingeniería. En verdad, estas florecieron gracias a la habilidad inca en copiar lo que grandes civilizaciones han dejado, algunas de las cuales merece la pena abordarlas más de cerca (Valcárcel, 2011).

Aproximadamente tres mil años antes de Cristo, existió la civilización Caral, la que fue, según la mayoría de los eruditos, una ciudadestado sagrada, y que tal vez haya sido la primera del continente, ubicada originariamente en un rincón desértico entre la costa y la selva de lo que hoy se llama Perú. Mantuvo intercambio comercial aventajado con las ciudades circunvecinas. Dicen de ella que es tan vieja como los primeros focos de civilizaciones en Mesopotamia, Medio Oriente, Egipto y China, pero diferentemente de estas, afirman los catedráticos, se mantuvo y se expandió sin necesidad de un ejército o milicias, porque no se ha encontrado improntas de batallas o de aparatos bélicos en ella.

Eso es una interpretación válida, pero cuestionable. Expandirse una nación sin un ejército que le de soporte es algo utópico, y la explicación es que a nadie le gusta ser dominado. Es eso lo que hace un imperio: imponer. Los de Caral fueron imperialistas y parece que vivieron bajo una teocracia, no obstante, sus líderes religiosos no poseían el status de dioses, como lo tenía el imperador inca. Ya conocían la agricultura, la siembra, la ganadería, las matemáticas rústicas, la arquitectura y eran grandes escultores.

Entre 1550 a.C. a 500 d.C., se destacó la sociedad Chavín, emplazada donde hoy está la Provincia de Huari en Perú (Cáceres, 1993). Se planteó ser ella de rasgos amazónicos, gracias a las distintas imágenes selváticas que dejó. Fue un gran centro irradiador de cultura, cuya influencia en la costa y sierra andinas es incuestionable. 
Las causas de la caída del Imperio Inca Bajo la perspectiva del Inca Garcilaso de la Vega: 297 una visión teológica del confronto entre el Conquistador Español y el Inca Atabualpa

De 100 a 800 d.C., hubo la cultura Nazca, responsable por los dibujos monumentales de personas, animales, bichos, etc., y que causan asombro cuando se les mira desde un avión.

Contemporáneo suyo fue la civilización de Lima, cerca de 200 a 700 d.C., en cuyos restos se ha erigido la actual Lima, por Francisco Pizarro, para servir de capital política del imperio colonial.

No se puede dejar de mencionar el imperio Tiabuanaco, cuyo intento fue el de unificar todas las civilizaciones andinas bajo un poder central; su origen parte de los alrededores del Lago Titicaca, cuyas construcciones se caracterizaban "por la arquitectura gigantesca de sus monumentos, construidos con enormes bloques de piedras irregulares, y por las estatuas que decoraban tales monumentos" (Cáceres, 1993, p. 25). Aquí, conforme a los estudiosos, comenzó la expansión imperialista armada, cuyos soldados se creían hijos del sol y que el mundo se había creado gracias al dios Wiracocha, oriundo del lago Titicaca. Fueron mui ingeniosos, quizás los mayores antes del inca, y de entre las tantas lenguas habladas en sus territorios el aymara y el quechua se destacaban.

Estas son apenas algunas de las civilizaciones de la región. En los Andes hubo siempre reinos en proceso de desarrollo económico, incluso con trazos capitalistas, globalizantes, expansionistas y bélicos. Esa expansión se debió a escasez de alimentos y tierras fértiles. En el intento de unificación sistemática, las ciudades tentaban interponerse unas sobre las otras. Cusco unificó el territorio que va desde Colombia, Ecuador, Perú, Argentina, Bolivia hasta Chile. Tal intento es bueno si se lo mira desde la perspectiva del conquistador, pero no así para el conquistado.

\subsection{La leyenda del buen indígena}

Las conquistas incaicas se daban por tres vías: a) la diplomacia, en la que los embajadores exponían la paz que generaba a los que vivían bajo los incas; b) los casamientos arreglados entre la nobleza incaica y la nobleza de los pueblos circunvecinos. Con todo, si ambas vías fallasen, vendría inevitablemente la guerra. Es decir, en nada distinto a las antiguas monarquías europeas.

Por consiguiente, se debe rebatir la leyenda que dice ser los indígenas pueblos pacíficos y sin intereses expansionistas. Muchísimas tribus indígenas vivían en considerable retraso, en términos de avances tecnológicos, pero en armonía consigo mismos y con su alrededor; otras, sin embargo, estaban 
en constantes guerras, por territorio, alimento o simplemente para aplastar a los enemigos. Tales pueblos eran imperialistas. No eran santos ni ángeles, sino hombres que, por variadas causas, no llegaron al nivel de desarrollo económico del europeo.

\subsection{Los incas y su cosmogonía}

Los incas son la última gran civilización precolombina de la región andina. Su existencia fue relativamente corta, sobre todo la fase aurea del imperio, cerca de cien años aproximadamente. Se constituían de un pequeño grupo étnico, sobre el cual hay muchas hipótesis respecto de su origen. Algunos dicen que vinieron de Europa o Asia y que cruzaron el estrecho de Bering; mientras otros señalan que eran una tribu originalmente andina. En términos científicos, no existe ninguna prueba concreta en cuanto a ello. Sin embargo, la mitología rellena este vacuo, por medio de tres leyendas, expuestas incluso por el Inca Garcilaso de la Vega (2013).

Un rasgo común entre los incas y las sociedades del Viejo Mundo está en la capacidad de inventarse para sí mitos y leyendas que justificasen el dominio sobre los demás. Según Garcilaso (2013), el inca se construyó mitos de origen para justificar su expansionismo, $y$, de los tres principales mitos originarios, dos eran más extendidos entre la "gente común", entretanto el otro correspondía a la nobleza. Entiéndase por "gente común” a los que pertenecían a los pueblos conquistados o a la gente inculta. He aquí las tres leyendas:

Los incas de Collasuyu y Cuntisuyu afirmaban que luego del diluvio surgió un hombre en Tiahuanacu, hombre este que dividió el mundo en cuatro partes iguales, y las dio cada una a cuatro príncipes, Manco Cápac, Colla, Tócay y Pinahua, para que las gobernasen. Garcilaso no lleva muy en serio esta leyenda, puesto que no estaba claro "si el diluvio los había (a los demás indios) ahogado o si los indios habían resucitado para ser conquistados y doctrinados" (Inca Garcilaso, 2013: 45).

La segunda leyenda es, conforme al Inca Garcilaso, la que profesaban los súbditos del norte y levante del Cusco. Para esta versión, desde el principio del mundo habían salido de las grietas de una peña en el sitio de Paucartampu ocho hermanos, cuatro hombres - Manco Cápac, Ayar Cachi, Ayar Uchu, Ayar Sauca - y sus respectivas mujeres.

La tercera leyenda oriunda de la nobleza incaica era considerada por él autor la más creíble. Esta versión le fue dada por un tío de su mamá, princesa de la corte de la corte incaica. Su tío señalaba a los incas como un 
Las causas de la caída del Imperio Inca Bajo la perspectiva del Inca Garcilaso de la Vega: 299 una visión teológica del confronto entre el Conquistador Español y el Inca Atabualpa

pueblo noble y justo y, en tanto, las tribus restantes que los precedieron o fueron contemporáneos vivían bajo idolatría de tal manera que los llenaba de salvajería:

Toda esta región de tierras que ves - le cuenta su tío - eran unos grandes montes y breñales, y las gentes en aquellos tiempos vivían como fieras y animales brutos, sin religión ni policía, sin pueblo ni casa, sin cultivar ni sembrar la tierra, sin vestir ni cubrir sus carnes, porque no sabían labrar algodón ni la lana para hacer de vestir; vivían de dos en dos y de tres en tres, como acertaban a juntarse en las cuevas y resquicios de peñas y cavernas de la tierra. Comían, como bestias, yerbas del campo y raíces de árboles y la fruta inculta que ellos daban de suyo y carne humana. Cubrían sus carnes con hojas y cortezas de árboles y pieles de animales; otros andaban en cueros. En suma, vivían como venados y salvajinas, y aun en las mujeres se habían como los brutos, porque no supieron tenerlas propias y conocidas (INCA GARCILASO, 2013, pp. 40-41).

Así, el dios principal de la dinastía inca, el sol, apiadándose de tanta violencia y bruteza envió dos de sus hijos dilectos, Manco Cápac y Mama Ocllo Huaco, para que les enseñara a los nativos buenos modales y el culto de alabanza a un único dios. Por medio del cronista, su tío añade:

-Nuestro Padre el Sol, viendo los hombres tales como te he dicho, se apiadó y hubo lástima de ellos y envió del cielo a la tierra un hijo y una hija de los suyos para que los doctrinasen en el conocimiento de nuestro Padre el Sol, para que lo adorasen y tuviesen por su Dios y para que les diesen preceptos y leyes en que viviesen como hombres en razón y urbanidad, para que habitasen en casas y pueblos poblados, supiesen labrar la tierra, cultivar las plantas y mieses, criar los ganados y gozar de ellos y de los frutos de la tierra como hombres racionales y no como bestias (INCA GARCILASO, 2013, p. 40).

Estos dos hijos eran a la vez hermanos y esposos y habían salido en formato humano desde las honduras del lago Titicaca:

Con esta orden y mandato puso nuestro Padre el Sol estos dos hijos suyos en la laguna Titicaca, que está ochenta leguas de aquí, y les dijo que fuesen por do quisiesen $\mathrm{y}$, doquiera que parasen a comer o a dormir, procurase hinca en el suelo una barrilla de oro de media vara en largo y dos dedos de grueso que les dio para señal y muestra, que, donde aquella barra se les hundiese con solo un golpe que con ella diesen en tierra, allí quería el Sol nuestro Padre que parasen e hiciesen su asiento y corte (INCA GARCILASO, 2013, p 40). 
El varón cargó consigo la barrilla de oro, y cuando ella se hundió definitivamente en la tierra la pareja supo que debería quedarse en región. Y sucedió que la barrilla se sumió justo en la región donde hoy está el Cusco.

\section{La crítica hacia el Inca Garcilaso}

Algunos comentaristas dicen que el enfoque de Garcilaso sobre la creación del Imperio inca está europeizado, es decir, el Inca Garcilaso había remodelado la crónica andina, imponiendo la mentalidad del conquistador sobre la del conquistado. La historia de los dos hermanos incas parecería a la del patriarca Abrahán y su esposa Sara. Estos eran medio hermanos, salieron de una tierra distante por mandato divino rumbo a una tierra prometida, habiendo sido designados para ser el candial que alumbraría los pueblos ahondados en un pantano de pecados. De hecho, los primeros padres de la fe judaico-cristiana hicieron todo eso, aunque la Biblia demuestre que, pese a la protección celestial, ambos cometieron varios pecados, uno de los cuales es el gran responsable por el actual conflicto israelí-palestino.

La versión del escritor peruano, con todo, da a los patriarcas incas la misma postura moral que apareció en los otros mitos andinos, es decir, los incas primordiales parecen casi perfectos al autoproclamarse el sendero que quitaría de las tinieblas los pueblos que vivían en el oscurantismo. Eso refuerza la supremacía inca, puesto que este mantiene su linaje noble y divina en relación al resto de la población andina. Entonces, la crítica no es solamente a causa de la mezcla de las ideas andinas con las europeas, sino también al hecho de que se mantenga la perspectiva de que el pueblo inca era el superior si comparado con los otros indígenas, siendo solamente vencido por otro grandioso imperio.

Lo más probable es que los primeros incas fueron una tribu pequeña que vino del Titicaca, hambrienta y en la esperanza de hallar tierra fértil, halló la región y la pobló. Enseguida, comenzó su proceso de expansión lenta pero gradualmente hasta convertirse en un imperio. Con todo, a la similitud de los españoles, la violencia de la conquista fue constante, puesto que, según el mito, el dios sol había expresamente dicho a los dos hermanos que se impusieran de forma abrupta sobre los pueblos aledaños:

Cuando hayáis reducido esas gentes a nuestro servicio, los mantendréis en razón y justicia, con piedad, clemencia y mansedumbre, haciendo en todo oficio de padre piadoso para con sus hijos tiernos y amados, a 
Las causas de la caída del Imperio Inca Bajo la perspectiva del Inca Garcilaso de la Vega: 301 una visión teológica del confronto entre el Conquistador Español y el Inca Atabualpa

imitación y semejanza mía, que a todo el mundo hago bien [...] Y desde luego os constituyo y nombro por reyes y señores de todas las gentes que así doctrináredes con vuestras buenas razones, obras y gobierno (INCA GARCILASO, 2013, pp. 40-41).

El propio Inca Garcilaso analiza el mito de forma política. Para él, Manco Cápac, astuto e ingenioso, inventó toda esta fábula para justificar el expansionismo inca y la manutención de los demás pueblos subyugados:

Lo que yo, conforme a lo que vi de la condición y naturaleza de aquellas gentes, puedo conjeturar del origen de este príncipe Manco Inca, que sus vasallos, por sus grandezas, llamaron Manco Cápac, es que debió ser algún indio de buen entendimiento, prudencia, y consejo, y que alcanzó bien la mucha simplicidad de aquellas naciones y vio la necesidad que tenían de doctrina y enseñanza para la vida natural, y con astucia y sagacidad, para ser estimado, fingió aquella fábula, diciendo que él y su mujer eran hijos del Sol, que venían del cielo y que su padre los enviaba para que doctrinasen e hiciesen bien a aquellas gentes (INCA GARCILASO, 2013, p. 59).

Esa visión más realista del mito permitiría otras desavenencias en contra del gran escritor peruano: él había investido duro en lo tocante a la cultura de sus ancestros de línea materna y condescendiente en demasía con los de línea paterna: la interpretación realista sobre el mito quitaría del mito el aire divino y lo pondría en la misma esfera que estaba el imperio español: la expansión territorial. Por ello, llaman al Inca Garcilaso traidor a la patria, puesto que se infiere de la interpretación susodicha ser los incas apenas un peldaño preparatorio para la llegada de la Iglesia romana. Para el escritor, la salvajería en que los pueblos anteriores al inca vivían era grotesca, y, de hecho, los incas domesticaron, calmaron, urbanizaron, construyeron grandes ciudades, etc., pero incluso así demostraban idolatría, puesto que alaban a una cosa criada, el sol, pero ya habían dejado la noción de que hay una fuerza suprema única, invisible y que rige toda la existencia. As, el imperio inca es tan solo un estadio preparatorio para el ingreso del cristianismo:

Viviendo o muriendo aquellas gentes de la manera que hemos visto, permitió Dios nuestro señor que de ellos mismos saliese un lucero del alba que en aquellas oscurísimas tinieblas les diese alguna noticia de la ley natural y de la urbanidad y respetos que los hombres debían tenerse unos a otros, y que los descendientes de aquél, procediendo de bien en mejor cultivasen aquellas fieras 
y las convirtiesen en hombres, haciéndoles capaces de razón y de cualquiera buena doctrina, para que cuando ese mismo Dios, sol de justicia, tuviese por bien de enviar la luz de sus divinos rayos a aquellos idólatras, los hallase, no tan salvajes, sino más dóciles para recibir la fe católica y la enseñanza y doctrina de nuestra Santa Madre Iglesia Romana [...] (INCA GARCILASO, 2013, p. 59).

Así, con la venida de los españoles, el trabajo de los incas ya se había completado, puesto que ellos, pese a su desarrollo y capacidad de organización social, justicia para con los conquistados y capacidad para alimentar a su pueblo, se mantuvieron bajo la idolatría del dios sol. Entonces cabría a la Iglesia combatir tal idolatría.

\section{Manco Cápac, Nemrod y los sacrificios de Sangre}

Para la tradición judaico-cristiana, la noción de dios sol es una de las más perniciosas, puesto que sus raíces se remontarían al bíblico Nemrod. Este hombre, jefe político y religioso de Babilonia, fue el primero en construirse un imperio y a proclamarse un dios. Asimismo, fue el primer conquistador de pueblos y constructor de grandes edificios, gracias al trabajo esclavo. Renegó a Dios y puso su confianza en su propio ingenio y astucia. Descendía de Can, cuya impiedad lo alejó de Dios.

Muchos pueblos en Oriente Próximo, adoraban a Nemrod, el Sol, y de esta adoración surgieron otras ramificaciones, cambiadas por la lengua y tradiciones de cada pueblo, pero con los mismos cimientos. Así, impulsados por la tradición egipcia, los israelitas en el desierto adoraron al dios Baal o Becerro de Oro, cuyo rasgo principal era la preocupación con la fertilidad, el oro, y la abundancia de las cosechas; sin embargo, para eso, cobraba de sus fieles sacrificios de sangre o rituales orgiásticos regados por vino.

Esta práctica también era común a fenicios, babilónicos, filisteos, etc., cada cual con su manera particular de entenderla.

De esta forma, Manco Cápac, se acerca bastante a Nemrod, puesto que se creó un imperio, mantuvo la gente arreglada, alimentada, mas no le quitó la idolatría ni los rituales de sangre. En cuanto a tales sacrificios, el Inca Garcilaso dijo no haber ocurrido, pero su contemporáneo, Guamán Poma de Ayala (apud Chacón, 2017), afirma que sí: según él, los incas sacrificaban anualmente a quinientos niños, mantenían los pueblos dominados bajo la intolerancia y que no eran queridos por muchísimos caciques del imperio. La ciencia ha demostrado que verdaderamente los incas poseían rituales de 
Las causas de la caída del Imperio Inca Bajo la perspectiva del Inca Garcilaso de la Vega: 303 una visión teológica del confronto entre el Conquistador Español y el Inca Atabualpa

sacrificios humanos, quizá no en gran escala como se pasaba en el Imperio azteca, pero los había.

Guamán Poma (apud Chacón, 2017), a diferencia de Garcilaso, no condescendió con la iglesia romana, y la atacó en sus errores. Él criticaba una rama del clero, pues consideraba que este no seguía las enseñanzas de Jesús, viviendo algunos curas bajo los deleites materiales. Así, apunta que, para los aborígenes andinos, pese a la idolatría en que vivían, el yugo del Imperio inca les había sido menos pesado, puesto que no hubo exterminio masivo y tantos prejuicios como les propinaron el español. Guamán Poma criticaba también la corona española, pues la consideraba indolente con la vida de sus súbditos indígenas.

Con todo, según dicen, Garcilaso fue ameno con las críticas hacia la Iglesia romana y la Corona. Debido a ello, algunos andinos sienten cierto desprecio hacia el Inca Garcilaso, pues saben que desde la conquista hasta la fecha la Corona y, después, los gobiernos criollos participaron directa o indirectamente de la consolidación de prejuicios hacia los pueblos precolombinos. Y no se olvidan de la participación también directa o indirecta de ciertas ramas de la Iglesia. Entonces, a lo mejor se cuestionen: ¿Qué dios es este que mata a su pueblo? Por consiguiente, a raíz del rencor contra las instituciones religiosas oficiales de antaño, terminan por confundirlas con las palabras de Cristo.

\section{La defensa del Inca Garcilaso}

El Inca Garcilaso de la Vega pertenecía a la nobleza de sangre inca y española: hijo de una princesa de la corte cusqueña, sobrina del imperador Huáscar, destronado por su medio hermano Atahualpa, y de un capitán y conquistador español, amigo de Francisco Pizarro. Creció entre dos noblezas, muy ligado a los valores paternos, y a la vez lleno de orgullo por pertenecer a la estirpe imperial.

El joven príncipe vivió tranquilo hasta que su padre abandonó la familia. La unión entre su papá y la princesa inca no era bien vista por la Corona española, la cual no aseguraba los derechos de herencia a la familia americana del capitán. Entonces, este volvió a España y allí se casó con una noble de su linaje, por lo que toda su herencia pasó a las manos de la segunda esposa.

Su padre, con todo, le dejó una parca cuantía en dinero, pero muy poca para atender las necesidades del príncipe. Así, este se dispuso a reclamar en 
España sus derechos, mas en vano, por dos motivos: uno, su padre había sido acusado de traición a la patria al aliarse con los soldados de Gonzalo Pizarro contra la Corona; dos, muy probablemente, su condición de hijo bastardo, noble perteneciente a un imperio recién vencido por España, no le daría las mejores atribuciones para reivindicar la fortuna. España no permitiría que una ibérica de sangre fuese preterida a un medio español. Por esta razón, quedaría en la relativa pobreza, eso si no fuera por algunos miembros de la familia de su padre, quienes le acogieron con dignidad.

En su estadía en la Península, empero, Garcilaso hizo algo digno de un análisis psicológico, entró al ejército español y combatió a los musulmanes. De hecho, ello ha permitido interpretaciones sobre su personalidad. En los combates, salió como héroe, recibiendo el título de capitán, igual que su padre, quien era conocido informalmente como el "mataindios"; Garcilaso, por su turno, fue un distinguido "matamoros". Y, tal como el progenitor, se enamoró de una mujer del bando enemigo, una esclava morisca, María de Flores, con quien convivió por años. Por todo ello, se infiere que tuvo conflictos psicológicos al no saber bien a qué mundo pertenecía.

También normal, por supuesto, que se alumbrara con las bellezas y logros de las ciudades españolas, que se encantase con los clásicos de la literatura y filosofía europeas, desde los antiguos hasta la contemporaneidad, que se maravillara con las profecías y verdades sublimes de la Biblia. Sin embargo, le ponían a prueba: los españoles le consideraban indígena en demasía y los indígenas le rechazaban por su sangre española. Así, medio apátrida, rechazado por los suyos en ambos lados del atlántico, necesitaba comprenderse a sí mismo. Por eso, llegó un momento en su vida que el lado indio suyo también exigió su lugar, por lo que intentó conciliar lo bueno de ambos mundos.

El hecho es que él, por ser inca y español, tenía cierta facilidad para disertar sobre ambas culturas. Necesitaba revivir el pasado glorioso de su pueblo inca, sin perder de vista la grandiosidad de España. Con todo, ante la mirada atenta del gobierno español, tenía que evitar enfrentarse a este, por lo que las críticas a la Corona y la Iglesia debían de ser muy sutiles, en vista de que España, de cierta manera, continuaba su guerra cruzada, no más contra el moro musulmán, sino contra las ideas iluministas y protestantes que venían del Norte. Por eso, las críticas más contundentes fueran hacia el andino no inca, como se vio más arriba, los veía como bárbaros y necesitados de liderazgo. 
Las causas de la caída del Imperio Inca Bajo la perspectiva del Inca Garcilaso de la Vega: 305 una visión teológica del confronto entre el Conquistador Español y el Inca Atabualpa

Pero no hubo como no criticar también a los incas, sobre todo en lo tocante a la cuestión política: ellos no eran queridos por todos los andinos, puesto que ciertas tribus estaban bajo su yugo opresor. Pizarro supo cómo utilizarse de ese fenómeno e incentivó las tribus enojadas a que se rebelasen contra Cusco. Sin estas, jamás el conquistador español lograría, con los pocos hombres que tenía, desmoronar el imperio incaico.

Hoy son justamente los herederos de los pueblos andinos, los que ayudaron a derribar el imperio inca, los que reclaman contra Garcilaso, lo apuntan como mentiroso o simplemente mal informado, que sus historias son más para entretener al colonizador que para rescatar la cultura andina.

Sin embargo, hay que mirar con atención el contexto de Garcilaso, quien era hombre del Renacimiento (Gutiérrez; Caliamano, 1940), de la misma forma que Camoes en Portugal hablaba de los dioses griegos, él hablaba de los incas, con un intento de abordaje sociológico y antropológico sobre la cuestión. En el periodo de publicación de los dos volúmenes de su obra maestra, 1606 y 1617, respectivamente, el contexto de la Península Ibérica era de reacción al liberalismo científico franco-germánico y al idealismo en relación a la cultura greco-romano, porque ambos trajeron a la moda el antropocentrismo antiguo.

Con la Reforma Luterana, la cristiandad occidental se dividió una vez más, y los conflictos armados entre católicos y protestantes no tardaron en venir. Asimismo, la batalla propagandística era común. En algunos momentos, el Renacimiento se ajustaba más a la mentalidad protestante, mientras el Barroco a la católica. La Iglesia romana fue la mayor de todos los mecenas renacentistas y barrocos, pero es indudable que el Barroco tiene su cuartel general en España. Numerosísimas obras de arte se deben al papel contrarrevolucionario católico-español. De la misma forma desde la Península Ibérica, se creó una ola de persecuciones a los libros, personas, artículos e instituciones que no compartieran los dogmas de la referida iglesia.

Por esta razón, los autores, incluso los más sinceros y corajudos, vivían un gran dilema: de un lado el Renacimiento y la Reforma direccionaban al hombre hacia dos puntos equidistantes: la primera, a la idealización del mundo greco-romano; la segunda, a un retorno al cristianismo primitivo a la lectura directa de la biblia sin la necesidad de intermediarios y comentaristas. Por su turno, la Contrarreforma aceptaba algunos valores del Renacimiento, pero combatía la perspectiva protestante. 
No por casualidad en Alemania, durante la Reforma, los libros de los doctores de la iglesia, Agustín, Santo Tomás, Santo Anselmo, etc. fueron quemados. Los reformistas se habían percatado de que los escritos de los referidos doctores mesclaban el humanismo greco-romano las palabras de Jesús, por veces en detrimento de estas últimas.

El retorno a las sagradas escrituras y su traducción a las lenguas vernáculas generaron un deseo de purificación del alma, lo que permitió, por ejemplo, el advenimiento del puritanismo. Con todo, era innegable el avance científico, las grandes navegaciones destruyendo mitos medievales, la ciencia propiciando mejoría de vida, nuevas técnicas de cultivo, universidades brindando al hombre posibilidades jamás antes podidas. Por ello, el sentimiento de contrabalancear la fe y la razón no fue algo exclusivo de los países que vivenciaron la Contrarreforma, sino un efecto de la Reforma, que en algunos casos se puso en contra de los avances renacentistas.

Por su turno, la iglesia escarmentaba ideales que contestasen sus doctrinas, tales como las ideas antropológicas que respetaban las distintas religiones y cultos de los otros pueblos. En consecuencia, publicar un libro que, de alguna forma, valorase el imperio inca, era enfrentarse a la corona e iglesia, sobre todo, si tales libros apuntasen los desmedros de la colonización.

Garcilaso supo tempranamente que el Imperio Inca ya era cosa remota, que, desgraciadamente, seguía el avance de la historia, puesto que los propios incas habían desbancado otras naciones y las había colonizado. La venida del europeo era un hecho.

\section{Atahualpa vs Huáscar: las causas de la caída del imperio}

Se han levantado algunas causas respecto a la caída del imperio: a) la profética; b) la religiosa; c) la política y la arrogancia de Atahualpa; d) la tecnología y astucia europeas.

\subsection{La profética}

Según Guamán Poma de Ayala (apud Chacón, 2017), el noveno inca, Pachacútec, había previsto que extraños vendrían a destruir el imperio. Eso ayudó a formatear la noción de que la conquista española era inevitable, en vista de que los propios incas ya la presentían. De alguna forma, el propio Garcilaso hace hincapié en ello al decir que los incas fueron solo un peldaño preparatorio para el cristianismo. 
Las causas de la caida del Imperio Inca Bajo la perspectiva del Inca Garcilaso de la Vega: 307 una visión teológica del confronto entre el Conquistador Español y el Inca Atabualpa

De hecho, para él, la forma como los mitos originarios incas se desarrollaron conlleva la interpretación de que los pueblos aledaños al Cusco vivían bajo la salvajería plena, por lo que vinieron los incas, a mando del sol, para pacificar, moralizar y combatir la idolatría. Sin embargo, los propios incas no fueron contundentes respecto a eso, al alabar a los dioses de los pueblos conquistados y, por supuesto, rendir culto a la criatura, el sol, en vez del Creador. Así, era imprescindible viniera una nueva cultura que terminase con los sacrificios de sangre, la poligamia del inca, el paganismo.

\subsection{La religiosa}

De esta forma, la Iglesia, para el autor, se torna el punto más alto en términos religiosos que va a continuar lo bueno dejado por los incas, y a erradicar lo malo diseminado por ellos. En este sentido es clara la ligación de las efemérides incaicas con la contundente promesa dada por Dios a Abrahán, a quien le dijo que los descendientes del patriarca se constituirían en miríadas de naciones tan numerosas como las estrellas. Es hecho que más de la mitad de la población mundial posee, espiritualmente hablándose, un vínculo con las tradiciones abrahámicas, sea por los lazos judaico-cristianos, sea por los musulmanes. Y eso se expande día tras día. Y no siempre por medio de la paz o argumentación, como lo preconiza y exige el texto sagrado. Hoy, pese a los excesos del catolicismo, es innegable que el cristianismo ha suplantado miles de religiones en Latinoamérica, y que actualmente miles de hombres y mujeres lo siguen con fervor acentuado, sobre todo si se refiere al cristianismo protestante.

Siguiendo esta línea de raciocinio era inevitable la hecatombe incaica. Así como los primeros cristianos, muchos de los cuales esclavos, pobres y maleantes arrepentidos, hallaban en las palabras de Cristo confort para seguir viviendo, muchos indígenas a lo largo del periodo colonial y actualmente hacen lo mismo. Es pavoroso lo que la corona y las repúblicas hicieron con el indígena, pero no se puede negar que el cristianismo ayudó a cicatrizar las heridas de muchos. Y desgraciadamente si la corona española fue cruel, las repúblicas no extirparon tal conducta, en algunos casos la agravaron.

Además, la violencia no era exclusiva de blancos, pues, pese los maltratos de europeos y criollos hacia el precolombino, no se puede dejar de ver que los incas persiguieron, asesinaron y destrozaron a sus enemigos, esclavizándoles, obligándolos a rehusar sus dioses en favor del dios inca. Aunque no se sepa con clareza el origen del inca, una cosa se tiene bien demostrado: ellos no eran santos. 
Hay escritores que intentan ponérseles un aura de bondad a los indígenas, atribuyendo todos sus males actuales tan solo a la mano dura del conquistador. Recién, en el Congreso de Lenguas realizado en Córdoba, Argentina, el rey español estuvo presente, y desde México el presidente Andrés Manuel López Obrador hizo una carta y se la envió al rey, exigiéndole que pidiera perdón por los males que hizo a los aborígenes.

En defensa de la corona, Mario Vargas Llosa, en el púlpito de una de las ponencias de dicho congreso, contestó al presidente mexicano. Le dijo que los males que afligen al indígena hoy no son apenas herencia del desprecio y violencia españoles, sino también fruto de la carnicería con la que los criollos continuaron las mismísimas políticas de sus pares ibéricos, y que hoy hipócritamente se las atribuyen solamente al conquistador. Incluso señaló a México que, a doscientos años de la independencia, no supo resolver el problema indígena, continuando las ofensivas a las tierras de los aborígenes.

Vargas Llosa atribuyó eso a la política demagógica con la que los latinoamericanos a veces echan la culpa de sus errores y fracasos a fuerzas extranjeras: a los ingleses, a los americanos, etc. Hay que buscarse a un chivo expiatorio para culparlo y así calmar el alma fatigada del criollo, que, mientras clama justicia contra el verdugo europeo, continuará permitiendo que el indígena sea humillado constantemente.

En verdad, para que las frases de López Obrador ganen fundamento sería necesario que todo heredero de la corona española, es decir, los criollos, todos los que tienen rasgos y sangre europea devolviesen a los indígenas todas las tierras y se marchasen de América. Incluso él, el presidente actual de México, por sus bien demarcados trazos españoles tendría que dejar su tierra.

Así como España fue invadida por cartagineses, romanos, musulmanes y hoy no es ningún de esos sino todos a la vez, en América pasa lo mismo. En Latinoamérica el problema es menos de orden étnico y cultural y más de orden económico. Los prejuicios surgen más a raíz de la pobreza. Sin embargo, como los indígenas están ahincado a la tierra, y esta es la fuente de ingresos de la mayoría de los países latinoamericanos, terminan los indígenas por ser expulsos de sus tierras, por no haber aprendido a tornárselas productivas conforme al modelo económico vigente. Así como los incas obligaban a sus conquistados a adaptarse al modelo político-económico del conquistador, lo mismo el capitalismo hace con las poblaciones aborígenes en todo el planeta.

Y cuando se intenta cambiar de sistema, ocurre lo que pasa en Cuba, por ejemplo, donde todos son iguales en pobreza inagotable. Tanto 
Las causas de la caida del Imperio Inca Bajo la perspectiva del Inca Garcilaso de la Vega: 309 una visión teológica del confronto entre el Conquistador Español y el Inca Atabualpa

capitalismo como comunismo son sistemas políticos-económicos ajenos a la mentalidad indígena, la esencia de tales sistemas es europea. Por ello, si hay que hablar de justicia social, tanto capitalistas como comunistas deberían abandonar la tierra y dejarla en las manos indígenas. Pero cuando si mira a un indígena uno se pregunta: ¿Es este puro indio o fruto de un montón de mixtura y mestizaje? América no es precolombina ni tampoco africana o europea, es una amalgama indisociable.

\subsection{La política y arrogancia de Atahualpa: Cusco versus Quito}

Aquí los teóricos se dividen en dos hipótesis: a) Atahualpa fue el gran responsable inmediato de la caída del imperio; b) al revés, fue Huáscar el culpable.

Huayna Cápac era padre de Huáscar y Atahualpa, hijos de madres distintas. El primero representaba el núcleo duro de la pura sangre inca; mientras el otro había nacido en tierras recién conquistadas por el imperio, siendo hijo del inca con la hija del curaca de la región tomada. Así, Huáscar personificaba el Cusco, el ombligo del mundo, capital incaica y del imperio; en tanto, Atahualpa, se identificaba con Quito, gran rival del imperio incaico. Eso explicaría por ejemplo el porqué del Perú y Ecuador, aunque extremamente parecidos en casi todo, poseer rivalidad hoy todavía.

Atahualpa era el más querido por el pueblo: guerrero nato y valiente, había participado de las conquistas de su padre y, por supuesto, estaba siempre con este. Huáscar era el cortesano, menos sanguíneo, algo como un playboy, algo mimado. Muerto el rey, la corona había que ser tomada por uno de los dos. Huáscar, era el predilecto de los cusqueños, mientras Atahualpa, de los de Quito. Por cuestiones de sucesión, Atahualpa no podía ser el rey, puesto que no pertenecía por línea materna a la elite inca, por eso Huáscar se tornó el inca absoluto.

Con todo, no demoró a estallar la guerra civil. La causa estaría en el hecho de que Huáscar poseía ideas revolucionarias, que seguro no agradarían a su padre. Era tradición antigua que, muerto el inca, en la región donde él fuese enterrado miles de hectáreas le pertenecerían, es decir, las tierras pertenecerían al difunto. Por lo general eran las más fértiles.

Para Huáscar, eso era prejudicial al desarrollo de la nación, puesto que tal costumbre serviría solamente para agradar a un clero sanguijuela, que vivía de las arcas públicas y que comandaban las huacas o cementerios de los reyes incas. 
Como el Estado era militar-religioso, Huáscar al tentar cambiar las cosas se metió en un avispero que le costaría la corona. Por ello, saliendo a proteger los intereses más antiguos de la tradición inca, Atahualpa se enfrentó a su hermano.

Según el Inca Garcilaso, Atahualpa fue el gran culpable. El cronista le consideraba el "Caín” incaico, usurpador y cruel, puesto que, tras la victoria en la guerra civil, habría actuado perversamente persiguiendo y asesinado a sus opositores. Eso es algo que la historia de las naciones está llena de ejemplos. Pero, para Garcilaso, Atahualpa no perdonó a nadie, incluso a los niños, puesto que cualquiera de la nobleza incaica podría ser un rey en potencial.

Por su turno, el propio comentarista es criticado por su supuesta parcialidad, en vista de que pertenecía al grupo de Huáscar, pues su mamá era sobrina de este. Por lo tanto, hacía parte del bando vencido. Entonces, hay que evaluar si las palabras del cronista peruano hacia Atahualpa son datos históricos o mera propaganda contra un rival político.

Lo cierto es que los españoles llegaron y han sido tenidos como el látigo de Dios contra el imperio inca, en general, y las actitudes de Atahualpa, en particular. Su padre ya sabía que algunos hombres blancos habían llegado, incluso el propio Atahualpa supo tempranamente, pero, impulsado por la curiosidad, por cuanto creía ser tales hombres dios o heraldos divinos. Esa idea pronto fue rechazada, en vista de que sus embajadores le dieron a Atahualpa la clara idea de la humanidad de los españoles.

Atahualpa estaba muy confiado, pues, durante la guerra, fue aprisionado y misteriosamente logró libertarse. Venció batallas durísimas y, de hecho, sus hazañas fueron brillantes. Sin embargo, cometió un error fatal: subestimó aquel puñado extranjeros. En el primero encuentro entre Atahualpa y Pizarro, aquel fue altivo y orgulloso, creyéndose de verdad una entidad divina, e intentando, por ello, impresionar a los españoles. Pizarro, siguiendo las huellas de Cortés, en México, quien había aprisionado el imperador azteca con el intento de dominar todo el imperio, hizo lo mismo con el inca. Atahualpa fue al encuentro sin soldados, se llevó apenas una gran comitiva de nobles, pero dejó el ejército alejado. No le pasó por la cabeza que aquel grupo tan reducido pudiera hacerle algún daño. Las huestes españolas, con sus balas y espadas, caballos y armaduras actuaron rápido y, milimétricamente, mataron los nobles que acompañaban al inca y a este lo capturaron.

Tras muchos días bajo cárcel, Pizarro le permitió a Atahualpa que comandara desde la prisión el reino, y una de las primeras órdenes del inca 
Las causas de la caída del Imperio Inca Bajo la perspectiva del Inca Garcilaso de la Vega: 311 una visión teológica del confronto entre el Conquistador Español y el Inca Atabualpa

fue mandar a asesinar a su hermano Huáscar. En términos políticos, quizá haya actuado correctamente, pues los enemigos de Atahualpa, ante la presente situación, podrían convencer a sus contrincantes a una alianza en la que Huáscar retornaría al poder. No obstante, en términos de lucha contra una fuerza extranjera, tal decisión fue un desastre. Huáscar, el legítimo imperador, podría ser el único quien mantendría el imperio unido contra una fuerza tan hostil y espectacular.

El odio prevaleció, y el orgulloso Atahualpa puso en jaque el futuro del imperio.

\subsection{La tecnología y astucia europeas}

Desde una perspectiva del verdadero Cristo, seguro eso sería abominable. Pero para la Ciudad de los Hombres, fue una jugada de genio. Espiritualmente, Francisco Pizarro y los suyos fueron extremadamente salvajes, infieles y monstruosos, pero para los adoradores de las ideas de Maquiavelo, nada más digno de alabanzas. Lo que hizo Pizarro está en el mismo nivel de lo hecho por los grandes generales de la historia. Un hombre podre, sin educación, pero con una voluntad hercúlea, se impuso como meta la gloria material.

El enfrentamiento a Atahualpa quizá no haya sido la mayor batalla de Pizarro para conseguir sus objetivos. Sus dificultades, como lo demuestra detalladamente Prescott (1980), realmente solo podrían ser superadas por un espíritu aguerrido.

Pese a todo eso, hay una diferencia entre la conquista del imperio azteca y el inca. Cortés poseía un ejército organizado y tuvo batalladas durísimas contra los aztecas. En el caso del dominio del imperio inca, principió por la captura de Atahualpa. Si este hubiese sido más prudente, quizá Pizarro no tendría ninguna chance de victoria.

Muy probablemente el imperio inca tarde o temprano caería, pero no de la forma como lo fue. Aunque hubo algunas décadas más, sobre todo en Vilcabamba, donde el pueblo inca luchó briosamente, el hecho de el soberano inca haber sido encarcelado fue duro golpe en las estructuras políticas y psicológicas del imperio. Por un lado, tal hecho contribuyó para que las naciones subyugadas se motivaran contra el poder central inca, puesto que percibió la oportunidad de libertad y que el inca no era tan invencible como lo demostraba.

Por otro lado, el abalo psicológico en el soldado fiel a Atahualpa debe de haber sido duro también. El imperador había vencido una guerra, en la que 
sus estrategias y logros reforzaron la idea de que el imperador inca provenía de los dioses. Pero, de pronto, es aprisionado y humillado por un grupo de hombres que, de alguna forma, hacía referencia a las viejas profecías sobre la caída del imperio. Sin la unidad, salido de una guerra civil, con el imperador legítimo muerto y Atahualpa preso, la reorganización militar fue débil.

Con todo, no se puede olvidar de la astucia de Pizarro y de sus armas de fuego. Fueron importantes, pues sin ambas cosas el líder español no lograría conquistar el imperio. Y si Atahualpa no hubiese sido engañado, los españoles tendrían que recular, organizar un verdadero ejército para luchar, a lo mejor por décadas, antes que el Cusco cayera.

\section{Conclusión}

En suma, desde una visión espiritual, las artimañas de Pizarro fueron dignas de reproche, sin embargo, humanamente hablándose se constituyeron en una hazaña espectacular, desplomando tal vez el mayor de todos los imperios precolombinos.

Para algunos teóricos contemporáneos, especialmente los herederos de las tradiciones andinas, criollos americanos y mestizos, que ven en el inca el ejemplo militar, es difícil admitir que los pocos soldados de Pizarro fueron superiores, por lo que intentan mermar las actitudes de los españoles atribuyendo sus logros solamente al avance tecnológico, al uso de caballos y perros de guerra. Seguro que eso conta, pero las amargas huellas de la guerra civil, el orgullo, o quizá ingenuidad, de Atahualpa también fueron fundamentales.

Es claro que las armas contribuyeron, la astucia también, pero el mayor enemigo del imperio inca, en este caso, ha sido su débil organización político-administrativa, pues si se hace un parangón con Roma, jamás esta se dejaría dominar solamente por el hecho de su emperador caer a manos de los enemigos. El inca se creó el mito de que era dios y obligó a sus súbditos a que se lo creyera, pero de forma extremadamente sumisa, así que, cayendo el rey, aquellos no supieron qué hacer.

\section{Referencias}

ARRUDA, Jose J. de A. História moderna e comtemporânea. Editorial Ática, São Paulo, 1990.

CÁCERES, Florival. História da América. Editorial Moderna, São Paulo, 1993. 
Las causas de la caída del Imperio Inca Bajo la perspectiva del Inca Garcilaso de la Vega: 313 una visión teológica del confronto entre el Conquistador Español y el Inca Atabualpa

CHACÓN, César. Los dibujos del cronista indio Guamán Poma. Kuskin Editores, Cusco, 2017.

COLÓN, Cristóbal. El diario de Colón. Biblioteca Virtual. Disponible en: http://www. biblioteca.org.ar/libros/130.pdf, 2003.

GUTIÉRREZ, Fermín Estrella; CALIMANO, Emilio Suárez. Historia de la literatura americana y argentina con antología. Buenos Aires: Editorial Kapelusz, 1940.

INCA GARCILASO. Comentarios reales de los incas. Ed. Vitruvian, Lima, Perú, 2013.

MAQUIAVELO, Nicolás. El príncipe. Disponible en http://www.ataun.net/bibliotecagratuita/ $\mathrm{Cl} \% \mathrm{C} 3 \% \mathrm{~A} 1 \mathrm{sicos} \% 20 \mathrm{en} \% 20 \mathrm{Espa} \% \mathrm{C} 3 \% \mathrm{~B} 1 \mathrm{ol} / \mathrm{Nicol} \% \mathrm{C} 3 \% \mathrm{~A} 1 \mathrm{~s} \% 20 \mathrm{Maquiavelo} / \mathrm{El} \% 20$ pr\%C3\%ADncipe.pdf

PLATÓN. La república. Disponible en: https://www.um.es/noesis/zunica/textos/ Platon,Republica.pdf

PRESCOTT, William H. Historia de la conquista del Perú. Tomo I, Ed. Peisa, Lima, 1980.

SANTA BIBLIA. Nueva Reina-Valera. Editorial New Life, Buenos Aires, 2003.

SAN AGUSTÍN. La ciudad de Dios. Ed. Porrúa, Argentina, 1981.

SILIO, Vicente. Nuevo manual de la historia de España. Ediciones iberoamericanas s/a, Madrid, 1969.

Submetido em: 12-6-2020

Aceito em: 16-11-2021 